\title{
pattern of blood cell parameters in thyroid dysfunction
}

\section{Mohamed Abd El Naser Elbastawesy ${ }^{1, *}$ M.B.B.Ch, Karima Abd-El-Halim Mahfouz ${ }^{1}$ MD, Amr Ahmed Rezk ${ }^{1}$ MD, Hossam Aladl Al Adl ${ }^{2}$ MD}

*Corresponding Author:

Mohamed Abd El Naser Elbastawesy

mohammedabdelnasr133@gmail.com

Received for publication October 22, 2021; Accepted January 14, 2022; Published online January 14, 2022.

Copyright The Authors published by Al-Azhar University, Faculty of Medicine, Cairo, Egypt. Users have the right to read, download, copy, distribute, print, search, or link to the full texts of articles under the following conditions: Creative Commons Attribution-Share Alike 4.0 International Public License (CC BY-SA 4.0).

doi: 10.21608/aimj.2022.101495.1617

${ }^{1}$ clinical Pathology Department, Faculty of Medicine, Al-Azhar University, Cairo, Egypt.

${ }^{2}$ Internal Medicine Department, Faculty of Medicine , Al-Azhar University, Cairo, Egypt.

Disclosure: The authors have no financial interest to declare in relation to the content of this article. The Article Processing Charge was paid for by the authors.

Authorship: All authors have a substantial contribution to the article.

\begin{abstract}
Background: Thyroid hormones are important in hematopoiesis, especially erythropoiesis. Thyroid dysfunction, including hypo and hyperthyroidism, are associated with variable hematological abnormalities, particularly anemia. Thyroid disorders are associated with not only quantitative hematological defects but also with functional abnormalities of blood cells.

Aim of the work: To evaluate the daily routine blood cell parameters with thyroid dysfunction (hyperthyroidism and hypothyroidism).

Patients and methods: This Prospective study was conducted from October 2020 and May 2021 at the clinical pathology department, AlAzhar University Hospitals, Cairo, Egypt. One hundred Egyptian patients suffering from thyroid dysfunction (hypothyroid and hyperthyroid) and fifty healthy volunteers (subjects without thyroid dysfunction) as a control group were enrolled in the study. History and clinical examination were done as well as the following laboratory investigations, complete blood count, blood smear, reticulocyte count, thyroid-stimulating hormone, free $\mathrm{T} 3$, and free $\mathrm{T} 4$.

Results: From our study, we found that WBC count and differentiation and platelet count and Retics have no significant association with hyperthyroidism or hypothyroidism patients. In the hypothyroid group, microcytic hypochromic anemia was a common finding. Some patients show anisocytosis. In the hyperthyroid group, some patients show mild microcytic hypochromic anemia with anisocytosis. Additionally, few patients show normocytic normochromic anemia.

Conclusion: Microcytic hypochromic anemia and anisocytosis were common findings in patients with hypothyroidism. Both normocytic normochromic anemia and microcytic hypochromic anemia were seen in hyperthyroidism patients. However, microcytic anemia was more common. Anisocytosis was frequently seen in both conditions.
\end{abstract}

Keywords: Thyroid dysfunction; Hyperthyroidism and Hypothyroidism; blood cell parameters.

\section{INTRODUCTION}

The biggest endocrine gland in the body is the thyroid gland. It produces and secretes 3, 5, 3'triiodothyronine (T3) and 3, 5, 3', 5'tetraiodothyronine (T4), also known as thyroxin. The anterior pituitary secretes thyroid-stimulating hormone (TSH) or thyrotropin, which regulates thyroid hormone function. Thyroid hormones are required for nearly all tissues' particularly for growth, differentiation, metabolic balance, and physiological function. Thyroid dysfunction is one of the most common endocrinal disorders. ${ }^{1}$

Hyperthyroidism, hypothyroidism, and thyroid nodules are the most common thyroid disorders. Thyroid nodules are benign but can turn into malignancy. ${ }^{2}$

Hypothyroidism is a clinical illness characterized by a reduction in thyroid hormone levels in the blood due to the hypo-functioning thyroid gland. ${ }^{3}$

Thyrotoxicosis is a medical disorder resulting from high levels of thyroid hormone that affects tissues of the human body. Increased hormone production and secretion from the thyroid gland causes hyperthyroidism, a kind of thyrotoxicosis. Graves' disease (GD) and toxic nodular goiter are the two most common causes of hyperthyroidism. ${ }^{4}$

Thyroid hormone receptors are found on bone marrow cells, and thyroid hormone levels in the blood can influence blood cell development. ${ }^{5}$

\section{PATIENTS AND METHODS}

This Prospective study was done from October 2020 to May 2021 at the clinical pathology department, Al-Azhar University Hospitals, Cairo, Egypt. The study included one hundred Egyptian patients suffering from thyroid dysfunction (hypothyroid and hyperthyroid patients) and fifty healthy volunteers (subjects without thyroid dysfunction) as a control group.

Inclusion criteria: Adult patients ( $>18$ years) suffering from thyroid dysfunction (hyperthyroidism and hypothyroidism). 
Exclusion criteria: Patients with chronic liver disease, chronic kidney disease, hematological diseases, autoimmune diseases, any diseases or drug intakes that could affect blood cell parameters, pregnancy, history of iron or vitamin supplementation in the previous 6 months, and acute illness history within at least 3 months prior to recruitment

\section{Samples and Methods:}

All patients underwent to the following a thorough history was taken, including any previous comorbid conditions such as diabetes, heart disease, or renal dysfunction.

Full Clinical Examination includes assessment of the general condition and vital signs. Abdominal, chest, and heart examinations were assessed with a focus on manifestations of the thyroid.

Blood sampling; two blood samples were collected from patients. $0.5 \mathrm{ml}$ of venous blood on EDTA tubes for CBC and $2.5 \mathrm{ml}$ of venous blood on a plain tube for thyroid hormonal assay.

The tubes containing EDTA were processed on a Sysmex XN-330 with five-parameter differential (Sysmex, Lincolnshire, IL, USA) for the determination of HCT (percent), $\mathrm{Hb}(\mathrm{g} / \mathrm{dl}), \mathrm{MCV}$ (fl/cell), MCH (pg/cell), MCHC (g/dl), RDW (\%), RDW (\%), and platelet (PLT). White blood cell differential was assessed using fluorescence flow cytometry.

The plain tube was then centrifuged for $20 \mathrm{~min}$ at $3000 \mathrm{rpm}$. Serum was obtained and stored frozen until use at $-20^{\circ} \mathrm{C}$. Using electro- chemiluminescence immunoassay (ECLIA) on Cobas e411 (Roche Diagnostics International Ltd, Basel, Switzerland), free FT3, free FT4, and TSH quantitative measurements were done according to the manufacturer protocol.

\section{Statistical analysis:}

Statistical Program for Social Science (SPSS) version 18.0 from IBM was used in the analysis of data. Mean \pm standard deviation (SD) was used to illustrate quantitative variables. Qualitative data were expressed as frequency and percentage. To equate proportions between two qualitative variables, the Chi-square (X2) test of significance was used.

\section{RESULTS}

As regard description of demographic data, the mean age of hypothyroid group was $44.1 \pm 10.3$ years, 13 were males $(26 \%)$. Regarding haematological parameters, results showed that the mean $\pm \mathrm{SD}$ of RBCs, HCT, Hb, MCV, MCH, MCHC, RDW, PLTs were $4.4 \pm 0.7 \times 106 / \mathrm{ul}, 36.1 \pm 6.3 \%, 11.2 \pm 2.0 \mathrm{~g} / \mathrm{dl}$, $68.2 \pm 9.5 \mathrm{fl} / \mathrm{cell}, 26 \pm 3.2 \mathrm{pg} / \mathrm{cell}, \quad 32.4 \pm 4.1 \mathrm{~g} / \mathrm{dl}$, $14.5 \pm 1.8 \%, 282.8 \pm 83.8 \times 106 /$ ul, respectively. The mean of total WBC, neutrophils, lymphocytes, monocytes, and eosinophils were $7.1 \mathrm{x} 103 / \mathrm{ul}, 4.3$ x103/ul, 2.5 x103/ul, 0.4 x103/ul, and 0.2 x103/ul, respectively. Among euthyroid group, the mean age was $44.6 \pm 7.1$ years, 16 were males $(32 \%)$. Regarding haematological parameters, results showed that the mean of RBCs, HCT, Hb, MCV,
$\mathrm{MCH}, \mathrm{MCHC}$, RDW, PLTs were $4.5 \mathrm{x} 106 / \mathrm{ul}$, $39.5 \%, 12.4 \mathrm{~g} / \mathrm{dl}, 81.7 \mathrm{fl} / \mathrm{cell}, 28.5 \mathrm{pg} / \mathrm{cell}, 34 \mathrm{~g} / \mathrm{dl}$, $13.4 \%, 274.4$ x106/ul, respectively. The mean of total WBC count, neutrophils, lymphocytes, monocytes, and eosinophils were $7.1 \mathrm{x} 103 / \mathrm{ul}, 4.1$ x103/ul, $2.6 \times 103 / \mathrm{ul}, 0.4 \times 103 / \mathrm{ul}$, and $0.2 \times 103 / \mathrm{ul}$, respectively .

The current study showed the prevalence of microcytic hypochromic anemia and anisocytosis in some patients. Anemia was significantly increased among hypothyroid patients in comparison with euthyroid subjects (50\% in hypothyroid patients and $24 \%$ in euthyroid subjects; $p$-value $<0.05$ ). The only type of anemia was microcytic hypochromic anemia.

As regard to patients with hyperthyroidism. The mean age was $44.6 \pm 7.1$ years, 16 were males $(32 \%)$. Regarding haematological parameters, results showed that the mean \pm SD of RBCs, HCT, Hb, MCV, MCH, MCHC, RDW, PLTs were 4.7 $\pm 0.8 \times 106 / \mathrm{ul}, 37.4 \pm 5.6 \%, \quad 11.3 \pm 1.9 \mathrm{~g} / \mathrm{dl}, 80.7 \pm 6.2$ fl/cell, $27.6 \pm 2.7 \mathrm{pg} / \mathrm{cell}, 32.8 \pm 3.9 \mathrm{~g} / \mathrm{dl}, 14.2 \pm 1.9 \%$, $283.2 \pm 94.0 \times 106 /$ ul, respectively. The mean of total WBC, neutrophils, lymphocytes, monocytes, and eosinophils were $7.9 \times 103 / \mathrm{ul}, 4.8 \times 103 / \mathrm{ul}, 2.3$ x103/ul, 0.5 x 103/ul, and $0.2 \times 103 / u l$, respectively .

Results of the current study showed that the prevalence of anemia was significantly increased among hyperthyroid patients in comparison with euthyroid subjects ( $42 \%$ in hyperthyroid patients and $24 \%$ in euthyroid subjects; p-value $<0.05$ ). Microcytic hypochromic anemia was the most frequent type of anemia (78.4\%), followed by normocytic normochromic anemia (28.6\%).

In table 1 , no statistically significant difference was reported between the studied groups regarding sex and age (P-value $>0.05)$.

As shown in table 2, no statistically significant difference was noted between the studied groups regarding TLC, neutrophil, lymphocytes, monocytes, eosinophil, and basophil (P-value > 0.05).

Reticulocyte count showed a non-significant difference between the studied groups, as shown in table 3. P-value $=0.477$.

As shown in table 4, a statistically significant association was reported between RDW and thyroid status $(\mathrm{P}$-value $=0.001)$.

$\mathrm{HCT}$ and $\mathrm{Hb}$ were significantly lower in the hypothyroidism and hyperthyroidism groups than in the normal group ( $\mathrm{p}$-value $<0.05$ ). In contrast, they were higher in the hyperthyroid group compared to the hypothyroid group ( $\mathrm{p}$-value $<0.05$ ).

RDW was significantly higher in hyperthyroidism and hypothyroidism groups than in the normal group (p-value < 0.05). Also, it was significantly higher in the hyperthyroid group than the hypothyroid group (p-value < 0.05).

$\mathrm{Hb}, \mathrm{MCV}$ and $\mathrm{MCH}$ were significantly lower in the hypothyroidism and hyperthyroidism groups than the normal group ( $\mathrm{p}$-value $<0.001$ ).

No significant differences were reported between the study groups regarding $\mathrm{RBCs}, \mathrm{MCHC}$, and platelets $(\mathrm{P}$-values > 0.05) 


\begin{tabular}{|c|c|c|c|c|c|c|c|c|c|}
\hline & & \multicolumn{6}{|c|}{ Groups } & \multirow{2}{*}{$\begin{array}{l}\text { Stat. } \\
\text { test }\end{array}$} & \multirow{2}{*}{$\begin{array}{l}P \text { - } \\
\text { value }\end{array}$} \\
\hline & & \multicolumn{2}{|c|}{$\begin{array}{l}\text { Normal } \\
(\mathbf{n}=\mathbf{5 0})\end{array}$} & \multicolumn{2}{|c|}{$\begin{array}{l}\text { Hypo } \\
(\mathbf{n}=\mathbf{5 0})\end{array}$} & \multicolumn{2}{|c|}{$\begin{array}{l}\text { Hyper } \\
(\mathbf{n}=\mathbf{5 0})\end{array}$} & & \\
\hline \multirow[t]{2}{*}{ Sex } & Male & 15 & $30 \%$ & 13 & $26 \%$ & 16 & $32 \%$ & \multirow{2}{*}{$\begin{array}{l}X^{2} \\
0.45\end{array}$} & \multirow{2}{*}{$\begin{array}{l}0.798 \\
\text { NS }\end{array}$} \\
\hline & Female & 35 & $70 \%$ & 37 & $74 \%$ & 34 & $68 \%$ & & \\
\hline \multirow[t]{2}{*}{ Age(years) } & Mean & 43.5 & & 44.1 & & 44.6 & & \multirow[t]{2}{*}{$\mathrm{F}=0.18$} & \multirow{2}{*}{$\begin{array}{l}0.830 \\
\text { NS }\end{array}$} \\
\hline & \pm SD & 8.9 & & 10.3 & & 7.1 & & & \\
\hline
\end{tabular}

Table 1: Correlations between studied groups as regards demographic data.

\begin{tabular}{|c|c|c|c|c|c|c|}
\hline & & \multicolumn{3}{|c|}{ Groups } & \multirow[t]{2}{*}{$\mathbf{F}$} & \multirow[t]{2}{*}{ P-value } \\
\hline & & $\begin{array}{l}\text { Normal } \\
(n=50)\end{array}$ & $\begin{array}{c}\text { Нypo } \\
(\mathbf{n}=\mathbf{5 0})\end{array}$ & $\begin{array}{c}\text { Hyper } \\
(\mathbf{n}=\mathbf{5 0})\end{array}$ & & \\
\hline \multirow{2}{*}{$\operatorname{TLC}\left(\times 10^{3} / \mathrm{ul}\right)$} & Mean & 7.1 & 7.1 & 7.9 & \multirow[t]{2}{*}{1.81} & 0.166 \\
\hline & \pm SD & 2.0 & 2.5 & 2.3 & & NS \\
\hline \multirow{2}{*}{ Neut.(x10 $/$ ul) } & Mean & 4.1 & 4.3 & 4.8 & \multirow[t]{2}{*}{2.4} & 0.087 \\
\hline & \pm SD & 1.07 & 1.84 & 2 & & NS \\
\hline \multirow{2}{*}{$\operatorname{Lymph}\left(\times 10^{3} / u l\right)$} & Mean & 2.6 & 2.5 & 2.3 & \multirow[t]{2}{*}{1.43} & 0.240 \\
\hline & \pm SD & 0.9 & 0.9 & 0.7 & & NS \\
\hline \multirow[t]{2}{*}{$\operatorname{Mono}\left(\mathbf{x 1 0} 0^{3} / \mathrm{ul}\right)$} & Mean & 0.4 & 0.4 & 0.5 & \multirow[t]{2}{*}{0.074} & 0.929 \\
\hline & $\pm \mathrm{SD}$ & 0.2 & 0.2 & 0.2 & & NS \\
\hline \multirow[t]{2}{*}{$\operatorname{Eosino}\left(\mathbf{x 1 0} 0^{3} / \mathrm{ul}\right)$} & Mean & 0.2 & 0.2 & 0.2 & \multirow[t]{2}{*}{0.23} & 0.793 \\
\hline & $\pm \mathrm{SD}$ & 0.2 & 0.2 & 0.2 & & NS \\
\hline \multirow[t]{2}{*}{$\operatorname{Baso}(\mathbf{x 1 0} / \mathrm{ul})$} & Mean & 0.01 & 0.01 & 0.018 & \multirow[t]{2}{*}{0.7} & 0.498 \\
\hline & $\pm \mathrm{SD}$ & 0.03 & 0.03 & 0.05 & & NS \\
\hline
\end{tabular}

Table 2 : comparisons between studied groups as regard WBCs count.

\begin{tabular}{|c|c|c|c|c|c|c|}
\hline \multirow[b]{2}{*}{ R.C (\%) } & \multirow{2}{*}{ Mean } & \multicolumn{3}{|c|}{ Groups } & \multirow[t]{2}{*}{$\mathbf{F}$} & \multirow[t]{2}{*}{ P-value } \\
\hline & & $\begin{array}{c}\text { Normal } \\
(\mathbf{n}=50)\end{array}$ & $\begin{array}{c}\text { Нypo } \\
(\mathbf{n}=50) \\
09\end{array}$ & $\begin{array}{c}\text { Hyper } \\
(\mathbf{n}=50) \\
102\end{array}$ & & \\
\hline & \pm SD & 0.5 & 0.4 & 0.5 & & \\
\hline
\end{tabular}

Table 3: comparisons between studied groups as regard reticulocyte count (RC).

\begin{tabular}{|c|c|c|c|c|c|c|c|c|c|}
\hline \multirow{4}{*}{ RDW } & \multirow[b]{3}{*}{ Normal } & \multicolumn{6}{|c|}{ Groups } & \multirow{4}{*}{$\begin{array}{l}\text { Stat. test } \\
X^{2}=\mathbf{1 3 . 2}\end{array}$} & \multirow{4}{*}{$\begin{array}{c}\text { P- } \\
\text { value } \\
\text { 0.001 } \\
\text { S }\end{array}$} \\
\hline & & \multicolumn{2}{|c|}{$\begin{array}{l}\text { Normal } \\
(\mathbf{n}=\mathbf{5 0})\end{array}$} & \multicolumn{2}{|c|}{$\begin{array}{c}\text { Нypo } \\
(\mathbf{n}=\mathbf{5 0})\end{array}$} & \multicolumn{2}{|c|}{$\begin{array}{c}\text { Hyper } \\
(\mathbf{n}=\mathbf{5 0})\end{array}$} & & \\
\hline & & 42 & $84 \%$ & 27 & $53 \%$ & 27 & $54 \%$ & & \\
\hline & Anisocytosis & 8 & $16 \%$ & 23 & $47 \%$ & 23 & $46 \%$ & & \\
\hline
\end{tabular}

Table 4: comparisons between studied groups as regard RDW.

\begin{tabular}{|c|c|c|c|c|c|c|}
\hline \multirow{4}{*}{$\begin{array}{c}\text { RBCs } \\
(\mathbf{x 1 0} / \mathrm{ul})\end{array}$} & \multirow[b]{3}{*}{ Mean } & \multicolumn{3}{|c|}{ Groups } & \multirow[t]{2}{*}{$\mathbf{F}$} & \multirow[t]{2}{*}{ P-value } \\
\hline & & $\begin{array}{l}\text { Normal } \\
(n=50)\end{array}$ & $\begin{array}{c}\text { Hypo } \\
(\mathbf{n}=\mathbf{5 0})\end{array}$ & $\begin{array}{c}\text { Hyper } \\
(\mathbf{n}=\mathbf{5 0})\end{array}$ & & \\
\hline & & 4.5 & 4.4 & 4.7 & \multirow[t]{2}{*}{2.4} & \multirow[t]{2}{*}{ 0.094 NS } \\
\hline & \pm SD & 0.6 & 0.7 & 0.8 & & \\
\hline \multirow[t]{2}{*}{ HCT (\%) } & Mean & 39.5 & 36.1 & 37.4 & \multirow[t]{2}{*}{4.8} & \multirow[t]{2}{*}{$0.009 \mathrm{~S}$} \\
\hline & \pm SD & 4.4 & 6.3 & 5.6 & & \\
\hline \multirow[t]{2}{*}{$\mathbf{H b}(\mathrm{g} / \mathrm{dl})$} & Mean & 12.4 & 11.2 & 11.3 & \multirow[t]{2}{*}{7.4} & \multirow[t]{2}{*}{$0.001 \mathrm{~S}$} \\
\hline & $\pm \mathrm{SD}$ & 1.2 & 2.0 & 1.9 & & \\
\hline \multirow[t]{2}{*}{ MCV (fl/cell) } & Mean & 81.7 & 68.2 & 74.3 & \multirow[t]{2}{*}{32.9} & \multirow[t]{2}{*}{$<0.001 \mathrm{HS}$} \\
\hline & \pm SD & 3.9 & 9.5 & 10.2 & & \\
\hline \multirow{2}{*}{$\begin{array}{c}\text { MCH } \\
\text { (pg/cell) }\end{array}$} & Mean & 28.5 & 26.0 & 27.6 & \multirow[t]{2}{*}{12.07} & \multirow[t]{2}{*}{$<0.001 \mathrm{HS}$} \\
\hline & $\pm \mathrm{SD}$ & 1.4 & 3.2 & 2.7 & & \\
\hline \multirow[t]{2}{*}{ MCHC (g/dl) } & Mean & 34.0 & 32.4 & 32.8 & \multirow[t]{2}{*}{2.95} & \multirow[t]{2}{*}{$0.055 \mathrm{NS}$} \\
\hline & $\pm \mathrm{SD}$ & 2.2 & 4.1 & 3.9 & & \\
\hline
\end{tabular}




\begin{tabular}{ccccccc}
\hline RDW $(\%)$ & Mean & 13.4 & 14.5 & 14.2 & $\mathbf{6 . 6}$ & $\mathbf{0 . 0 0 2 ~ S}$ \\
& \pm SD & 1.1 & 1.8 & 1.6 & & $\mathbf{0 . 8 4 9}$ NS \\
PLTs & Mean & 274.4 & 282.8 & 283.2 & $\mathbf{0 . 1 6}$ & \\
$\left(\mathbf{x} 10^{3} /\right.$ ul $)$ & \pm SD & 82.4 & 83.4 & 94.0 & & \\
\hline
\end{tabular}

Table 5 : comparisons between studied groups as regard RBCs, indices \& PLTs.

\section{DISCUSSION}

In the current study, we aimed to assess the daily routine blood cell parameters with thyroid dysfunction. This study was conducted on One hundred Egyptian patients suffering from thyroid dysfunction (50 hypothyroid and 50 hyperthyroid patients). Fifty euthyroid individuals have been chosen as a control group. The control subjects were selected age and sex-matched with the patients. As regards the description of demographic data, the mean age of the hypothyroid group was $44.1 \pm 10.3$ years, 13 were males $(26 \%)$.

The current study showed the prevalence of microcytic hypochromic anemia and anisocytosis in the hypothyroid group comparable to the normal group.

The results of the current study matched that of Dorgalaleh et al. ${ }^{2}$. They studied 102 patients with hypothyroid (14.1 years) and 118 controls (15.2 years). Their results revealed a statistically significant decrease in the RBC count, HB, HCT, $\mathrm{RDW}, \mathrm{MCH}, \mathrm{MCHC}$, and $\mathrm{MCV}(\mathrm{P}$-value $<0.05)$. However, no significant differences were observed for platelet count and WBC (P-value $>0.05){ }^{2}$

Saba et al. $^{6}$.examined 79 individuals with hypothyroidism in line with the current study. Patients were split into two groups: those with moderate hypothyroidism (TSH 6-10 IU/mL) and those with severe hypothyroidism (TSH $>10 \mathrm{IU} / \mathrm{mL}$ ). They found a statistically significant difference in RBC count (4.46 vs. $4.04 \mathrm{mil} / \mathrm{L})$, hemoglobin (12.8 vs. $12.3 \mathrm{~g} / \mathrm{dl})$, and hematocrit (39.8 vs $38.0 \%)$ between the two groups. ${ }^{6}$

The current study findings are also similar to those of Islam et al. ${ }^{7}$.who carried out a cross-sectional study on 452 women of various ages. A positive correlation between hypothyroidism and iron deficiency anemia (IDA) in women was found in this study, as $24.69 \%$ of patients with IDA aged 0-60 years were found to have hypothyroidism concurrently, with the highest rate $(38.46 \%)$ among those aged $31-40$ years. Also, $26 \%$ of iron-deficient females of reproductive age (15-49 years) had hypothyroidism. ${ }^{7}$

Das et al. ${ }^{8}$ performed an Indian study on hypothyroidism patients and found that the prevalence of microcytic anemia was $43.3 \%{ }^{8}$

In accordance with the current study, Rad et al. ${ }^{9}$ evaluated 90 adults (aged 19-42 years) divided into two groups: hypothyroid patients who were not on thyroxin or antithyroid drugs at the time of sample collection $(\mathrm{n}=45)$ and healthy control subjects $(n=45)$. They reported that the total iron-binding capacity, serum iron, ferritin, Hemoglobin, and
Hematocrit were significantly lower in hypothyroid patients compared to the control group $(\mathrm{p}<0.05) .{ }^{9}$

In accordance with the current study, Ahmed and Mohamed. ${ }^{10}$ evaluated 45 newly diagnosed cases of hypothyroidism aged 35-50 years and compared them with 45 healthy individuals as a control group. There was a significant decrease in hemoglobin, serum iron, and ferritin while a significant increase in total iron-binding capacity in hypothyroid patients compared to the control group $(\mathrm{P} \leq 0.05) .{ }^{10}$

Regarding the blood smear, in patients with hypothyroidism, microcytic hypochromic anemia was a common finding. Some patients show anisocytosis, and others show as well macrocytosis with few acanthocytes in their blood smear. The macrocyte was oval in shape, pointing to megaloblastic anemia. Leucocytes count and morphology were normal in the majority of the patient, whereas few smears show hypersegmentation of neutrophils. This hypersegmentation revealed in the blood smear pointing to megaloblastic anemia. Basophilia was noted particularly in those receiving thyroid hormone treatments. Platelet counts were generally normal, with few exceptions of mild thrombocytopenia. No abnormalities in the size or shape of platelets were seen.

Results of the current study showed that the prevalence of microcytic hypochromic anemia followed by normocytic normochromic anemia with anisocytosis was significantly increased among hyperthyroid patients in comparison with euthyroid subjects.

In a study by Geetha and Srikrishna. ${ }^{11}$ included 273 subjects, among which $21 \%$ were males, and $79 \%$ were females, there were 146 euthyroid and 42 hyperthyroid subjects. They observed that RDW and MCV have a statistically significant decrease in comparison to euthyroid individuals. ${ }^{11}$

The results of the current study were comparable to those done by Ahmed and Mohammed. ${ }^{10}$ in which the analyses showed a significant decline in $\mathrm{HB}$, RBC, MCV, MCHC. ${ }^{10}$

The present study findings are consistent with those of Omar et al. ${ }^{12}$ who found an extremely high prevalence $(87.7 \%)$ of microcytic anemia in individuals with hyperthyroidism independent of hemoglobin status ${ }^{12}$.

Azizi et al. ${ }^{13}$ discovered a correlation between the incidence of goiter and serum ferritin levels in Iranian school children and concluded that goiter was associated with iron deficiency. ${ }^{13}$

The current study findings were consistent with those of Maheshwari et al. ${ }^{14}$ in which a statistically significant reduction in $\mathrm{Hb}, \mathrm{MCV}$, and $\mathrm{MCH}$ levels 
was reported between thyroid patients and controls $(\mathrm{P}<0.05){ }^{14}$

According to research conducted by Jafarzadeh et al., ${ }^{15}$ the MCV was significantly lower in individuals with hyperthyroidism than in those with euthyroid state, which corroborates our findings. The current study's findings indicate a statistically significant increase (P-value 0.05) in RDW between the euthyroid and hyperthyroid groups. Anisocytosis was significantly more prevalent in the hyperthyroid group than in the euthyroid group. ${ }^{15}$

According to the current study, Geetha and Srikrishna, ${ }^{11}$ discovered higher RDW in hyperthyroid and hypothyroid patients when compared to the euthyroid group, suggesting that thyroid hormone imbalances may affect the size of RBCs. ${ }^{11}$

The results of the current study matched those done by Maheshwari et al. ${ }^{14}$ who reported a statistically significant increase $(\mathrm{p}<0.05)$ in Red cell distribution width (RDW) between hyperthyroid cases and controls. ${ }^{14}$

In accordance with the current study, Dorgalaleh et al., ${ }^{2}$ reported that WBC and PLT counts did not show any statistically significant difference between these groups $(\mathrm{P}$-value $>0.05){ }^{2}$

Regarding the blood smear, Red blood cells in the majority of patients with hyperthyroidism show no abnormalities. However, some patients show mild microcytic hypochromic anemia with anisocytosis. Additionally, few patients show normocytic normochromic anemia but with normal red cell distribution width. No hematological abnormalities apart from the hypochromia and the macrocytosis could be seen in the blood smear. Regarding white blood cells, all patient results were within the normal reference range for age but with a tendency towards the upper limits. No morphological abnormalities were detected apart from few neutrophils with toxic granulation. Platelets in most of the patients were normal in count and shape with mild platelet anisocytosis. Nevertheless, the minority of patients have mild thrombocytopenia with evidence of anisocytosis and some large platelets.

\section{CONCLUSION}

Having the aforementioned results, we can conclude that microcytic hypochromic anemia is a common finding in hypothyroidism patients. No evidence of megaloblastic anemia except in few patients. Additionally, both microcytic hypochromic anemia and normocytic normochromic anemia are seen in patients with hyperthyroidism. However, microcytic anemia was more common. Anisocytosis is frequently seen in both conditions. No evidence of hemolytic anemia.

\section{REFERENCES}

1. Panna k. kamdar and Avani V. Mendepara. .To study hematological abnormalities in patients of thyroid dysfunction, international journal of scince research,2019; Volume-8 | Issue-12 , 627-31
2. Dorgalaleh A, Mahmoodi M, Varmaghani B, Kiani node $\mathrm{F}$, Saeeidi Kia $\mathrm{O}$ et al . Effect of thyroid dysfuctions on red blood cell count and red blood cell indice. Iranian Journal of Pediatric Haematology Oncology. 2013; 3: 73-7

3. Alemu, A., Terefe, B., Abebe, M., \& Biadgo, B.. Thyroid hormone dysfunction during pregnancy: A review. International journal of reproductive biomedicine, 2016; 14(11), 677-86.

4. Braverman LE, Cooper D. Werner and Ingbars the Thyroid: A Fundamental and Clinical Text (Werner and Ingbars the Thyroid) Tenth Edition. Philadelphia, PA: Lippincott Williams and Wilkins, 2012; 236-44

5. Chute JP, Ross JR, McDonnell DP . Minireview: nuclear receptors, hematopoiesis, and stem cells. $\mathrm{Mol}$ Endocrinol, 2010; 24:1-10.

6. Saba F, sayyadipoor F. The Relationship between Severity of Hypothyroidism and Red Blood Cells Indices. IJML.2019; 6 (1) :16-20

7. Islam, R., Akter, K. M., Rahman, A., Khanam, N. N., et al . The Serological Basis of the Correlation between Iron Deficiency Anemia and Thyroid Disorders in Women: A Community Based Study. Journal of Pharmaceutical Research International, 2021; 33(19A), 69-81.

8. Das C, Sahana PK, Sengupta N, et al . Etiology of anemia in primary hypothyroid subjects in a tertiary care center in Eastern India. Indian $J$ Endocrinol Metab. 2012; 16: S361-S3.

9. Rostaei Rad N, Vakili M, Zavar-reza J, Rezaie S, Shirvani A R. The Relationship between Thyroid Hormone Levels and Body Iron Status in Iranian Hypothyroidism Patients. IJML. 2016; 3 (3) :176-84

10. Ahmed SS and Mohammed AA . Effects of thyroid dysfunction on hematological parameters: Case controlled study. Ann Med Surg (Lond). 2020; Sep; 57: 52-5.

11. Geetha , Srikrishna R . Role of red blood cell distribution width (rdw) in thyroid dysfunction. Int. J. Biol. Med. Res. 2012; 3(2):1476-1478

12. Omar S, Hadj Taeib S, Kanoun F . [Erythrocyte abnormalities in thyroid dysfunction]. Tunis Med. 2010; 88:783-8.

13. Azizi F, Mirmiran P, Sheikholeslam R, Hedayati M, Rastmanesh R. The relation between serum ferritin and goitre, urinary iodine and thyroid hormone. Int $J$ Vitam Nutr Res. 2002; 72: 296-299.

14. Maheshwari KU, Rajagopalan B and Samuel TR . Variations in Hematological Indices in Patients with Thyroid Dysfunction. International Journal of Contemporary Medical Research. 2020; 7 (1) : 24547379.

15. Jafarzadeh, A., Poorgholami, M., Izadi, N., Nemati, M., \& Rezayati, M. Immunological and hematological changes in patients with hyperthyroidism or hypothyroidism. Clinical and investigative medicine. Medecine clinique et experimentale, 2010; 33(5), E271-E9. 